\title{
Contesting Intellectual Crisis: Michael D. Higgins and the Irish Postcolonial Mind
}

\section{Alfred Michael Markey}

\section{(2) OpenEdition Journals}

Electronic version

URL: http://journals.openedition.org/etudesirlandaises/4563

DOI: 10.4000/etudesirlandaises. 4563

ISSN: 2259-8863

\section{Publisher}

Presses universitaires de Rennes

\section{Printed version}

Date of publication: 30 June 2015

Number of pages: $241-258$

ISBN: 978-2-7535-4082-8

ISSN: 0183-973X

Electronic reference

Alfred Michael Markey, «Contesting Intellectual Crisis: Michael D. Higgins and the Irish Postcolonial Mind », Études irlandaises [Online], 40-1 | 2015, Online since 30 June 2017, connection on 20 April 2019. URL : http://journals.openedition.org/etudesirlandaises/4563 ; DOI : 10.4000/ etudesirlandaises.4563 


\title{
Contesting Intellectual Crisis: Michael D. Higgins and the Irish Postcolonial Mind ${ }^{1}$
}

\author{
Alfred Michael Markey \\ Universitat Jaume I, Castellón
}

Abstract

Since his election in 2011 Michael D. Higgins, President of Ireland, has proposed that his would be a presidency of ideas and one sensitive to language. Central to this proposition has been the defence of the figure of the public intellectual. His own diverse trajectory as an academic, a poet and as a politician conscious of the need to bring culture and ideas into the public sphere gives authority to what is, in effect, an ideological position. In this article I will address the importance of such a proposition in relation to Irish intellectual traditions, particularly that of postcolonial critique and Irish emancipatory politics.

Keywords: Michael D. Higgins, public debates, intellectuals, social role of the artist, postcolonialism, identity - national

\section{Résumé}

Depuis son élection à la magistrature suprême irlandaise en 2011, Michael D. Higgins a souhaité que son mandat soit marqué par la souveraineté des idées et la sensibilité à la langue. Au cour de son projet se trouve la défense de la figure de l'intellectuel public. Son propre parcours diversifié en tant qu'universitaire, poète et homme politique conscient du besoin de placer la culture et les idées au cour de la sphère publique donne autorité à ce qui est, en fait, une position idéologique. Dans cet article, j'analyserai l'importance d'un tel projet dans le contexte des traditions intellectuelles irlandaises, et surtout celle de la critique postcoloniale et de la vision irlandaise d'une politique d'émancipation.

Mots clés : Michael D. Higgins, débat et sphère publics, intellectuels, rôle social de l'artiste, postcolonialisme, identité - nationale

In the foreword to the 2006 collection of writings and speeches by the current President of Ireland, Michael D. Higgins, Causes for Concern, Irish Politics, Culture and Society, his friend and fellow academic Declan Kiberd wrote that while he lamented the fact that his colleague's commitment to politics meant that he had moved away from academic life he did, nonetheless, find compensation in the rea-

1. A version of this article was delivered at the XI AEDEI conference held at the University of Huelva, Spain, in 2012. 
lisation that Higgins had brought imagination into politics, citing the example of how during a "particularly extended set of debates on land inheritance" " he had managed to read his way through a couple of novels by Thomas Mann.

Although Higgins gave up his post as lecturer in sociology and politics at the university in Galway when he became Minister for Arts, Culture and the Gaeltacht in the early 1990s, this did not involve a disengagement from one professional realm in order to "properly" enter another. Indeed, for much of his political career, Higgins has, for example, simultaneously engaged in the creation and publication of poetry ${ }^{3}$. Academic, poet, politician, intellectual, scholar, public intellectual and recently President of Ireland: the man is anything but simple. In a sense he defies classification.

This protean characteristic is not of casual importance but goes to the heart of Higgins's vision of what the role of the intellectual should be and, indeed, "where" it should be. Whether as poet, academic or politician, he does not belong to just one realm, place or institution but conceives of these activities as taking place also within a broad public space which is the place of democracy, a place not just of political but also cultural engagement. As Kiberd writes:

Democracy for this man is the dissemination of a common culture as widely as possible among a people audacious enough to imagine their own present and future. It is not to be confused with ease of access by trained technocrats to this or that managerial elite. At its core is an educational ideal based on the principle that learning is life-long but never quantifiable, a process rather than a product, a humanistic challenge rather than a technical qualification ${ }^{4}$.

Kiberd's words were written in 2006 but they take on a particular resonance when considered in the light of Higgins's election in 2011 to become the Republic of Ireland's "top man", the nation's MD, so to speak.

If the employment of the jargon of business-speak here strikes a dissonant note, it is, nonetheless, relevant in view of the fact that it was precisely the sort of language which set the parameters within which the race for the Irish presidency took place, with much public commentary favouring the election of a candidate whose profile was compatible with the values of the business world. In short, in times of economic crisis many felt that exactly what was needed was a good "MD" to lead Ireland Inc. or "Ireland Plc.". This role was taken by Sean Galla-

2. Declan Kiberd, "Foreword", Causes for Concern: Irish Politics, Culture and Society, Michael D. Higgins, Dublin, Liberties Press, 2006. p. 12.

3. Higgins has published four collections of poetry: The Betrayal, Clare, Salmon, 1990; The Season of Fire, Dingle, Brandon/Mount Eagle, 1993; An Arid Season, Dublin, New Island, 2004, and New and Selected Poems, Dublin, Liberties, 2011.

4. Declan Kiberd, "Foreword", op. cit., p. 12. 
gher, a self-styled entrepreneur best known for his role as a panellist on the reality TV show "Dragon's Den". Certainly the contest made for gripping viewing, but it was a worrying reminder of the extent to which large numbers of the Irish population seem to have uncritically bought into the ideology of modernisation and the aggressive codes and language of what Higgins has frequently called "extreme individualism". Also, given the perceived urgencies in a time of crisis and the apparent need for a supposedly objective, non-ideological pragmatism, proposals of apparently less practical alternatives were mostly met with impatience.

Eventually, a very dramatic climax was reached days before the vote when on a TV debate the Sinn Féin candidate, Martin McGuinness, definitively undermined the campaign of the clear frontrunner by revealing some unsavoury past dealings involving possible illegal payments. Gallagher's campaign collapsed in an instant, and suspicion remains that McGuinness's action was to a degree facilitated by insiders of the state broadcaster, RTÉ, who were similarly unimpressed by the idea that Gallagher would become President. Perhaps of ultimate importance was the realisation that the "top job" was not a job for a man of action, whether in the Gallagher or McGuinness mould, but that, rather, given its largely symbolic role, it was more suited to the poet, the man of ideas.

And since his election President Higgins has not been shy about identifying himself as a poet and an intellectual, and has made some very significant speeches which address precisely the clash of values apparent in the election itself. Indeed, from the beginning, Higgins proposed that his would be a presidency of ideas and one sensitive to language. In this article I will address the importance of such a proposition, particularly in relation to Irish intellectual traditions and Irish emancipatory politics.

Of particular significance are two speeches given to academia, one to the National University of Ireland, entitled "The role of the University at a time of intellectual crisis", and the later "Of Public Intellectuals, Universities, and a Democratic Crisis" given to the London School of Economics. Both overlap to a considerable extent, but as is evident in the titles, there is a more emphatic quality to the latter in which it is stressed that an intellectual crisis has as its real consequence a democratic crisis.

Higgins is largely addressing academics, and he firmly puts it to them that they have an ethical obligation as an educated elite to take a stand against the increasingly aggressive orthodoxies of the marketplace. He emphasises the importance of universities as "communities of learning, teaching, disputation and per-

5. Michael D. Higgins, "The Role of the University at a Time of Intellectual Crisis", [www.president.ie/speeches/], 2012.

6. Michael D. Higgins, "Of Public Intellectuals, Universities, and a Democratic Crisis”, [www.president.ie/speeches/], 2012. 
sonal and social development", and he asks "Is it not as important to experience the development of the self and one's connection to citizenship and history as it is to become a useful unit in a consuming culture? Universities function within a culture and how they negotiate that relationship defines their atmosphere, their ethos ${ }^{7}$. He then goes on to clarify that

Intellectuals are challenged, I believe now, to a moral choice, to drift into, be part of, a consensus that accepts a failed paradigm of life and economy or to offer, or seek to recover, the possibility of alternative futures. And were universities not special places, the citizens of the future may ask, for the generation of alternatives in science, culture and philosophy? The universities have a great challenge in the questions that are posed now, questions that are beyond ones of a narrow utility8.

Higgins clearly wishes to address the malady which he identifies within the Irish academy, where the hegemonic utilitarian values are impacting on the quality of intellectual enquiry and the public sphere - for example the consequence that the simplicities of reality-show speak become the discourse of political debate. However, he also wishes to widen the framework and to make connections beyond the local sphere and in relation to broader global tendencies? In a sense, this parallels the attempt to promote engagement between the place of professional specialism and a broad public. Against what he considers a commodification which turns active citizens into passive consumers, static and silent in their allotted place, Higgins promotes for the universities a paradigm of engagement with the world. This paradigm necessitates a dialogue away from specialist jargon to a broad vibrant public space, but retains for the university a capacity to be different, to be the source of critical ideas: ideas, languages and tropes which can resist the diktats of the marketplace which demand everyday utility. And, indeed, one can argue that this is exactly what was achieved by the election of a poet to the top job in the land.

We have, then, proposed a relationship between the university and the world marked by interconnection. This is a key word for Higgins ${ }^{10}$. In the face of the overwhelming pressure of commodification and market values, Higgins proposes:

7. Higgins, "The Role of the University".

8. Ibid.

9. There has been little debate on this issue in Ireland. Exceptions include Tom Garvin's polemic "The Bleak Future of the Irish University", The Irish Times, 1 May 2012; the essay collections, Mary Corcoran and Kevin Lalor (eds.), Reflections on Crisis: The Role of the Public Intellectual, Dublin, Royal Irish Academy, 2012; Brendan Walsh (ed.) Degrees of Nonsense: The Demise of the University in Ireland, Dublin, Glasnevin, 2012; and the special issue of Etudes Irlandaises, "Representations of the Intellectual in Ireland", no 34.2, 2009. In the UK the issue has been addressed primarily by Stefan Collini. See particularly Stefan Collini, What Are Universities For?, London, Penguin, 2012.

10. For Higgins a clear contrast exists between "interconnection" as a paradigm for human interaction and what he 
It is a challenge for all of us to craft a response. I believe that an Irish university response that is critically open to originality in theory and research, committed to humanistic values in teaching, has a great opportunity to make a European, even global, contribution of substance; that Ireland can be the hub of original, critical thought and a promoter of its application through new models of connection between science, technology, administration and society; that our best contribution might be to issue an invitation to come and think with us, be original, in Ireland. Independent thought, from home and abroad, and scholarly engagement with our current circumstances are crucial $^{11}$.

"Genuinely emancipatory scholarship ${ }^{12 "}$, he insists, is based on originality not imitation and does not, for example, involve a strict division between the sciences and culture.

Notably, in the speech "Of Public Intellectuals, Universities and a Democratic Crisis", Higgins, in effect, puts into practice what he proposed in the Irish university through his use of carefully chosen imagery, examples and vocabulary. Addressing the LSE, he highlights particularly the figure of the creative writer as public intellectual. This is his territory, and he begins by stating that as an Irishman he feels at home in a city with so many Irish connections, including one of the key intellectual parents of the LSE, Irish writer and public intellectual, George Bernard Shaw. As Higgins notes, Shaw was a Fabian and his ideology involved challenging the raw edge of capitalism but in a manner which looked for alternatives to the clash and violence of class conflict. To this Higgins also relates Shaw's "interest in the social change he saw as necessary in Ireland and the place of literature in the consciousness that would demand and deliver that change $\mathrm{e}^{13}$ ".

Higgins then goes on to show how Shaw's ideas, via the Irish journalist Frederick Ryan, came to influence key Irish anti-colonialists such as James Connolly. As he says:

This connection between London and Dublin, this flow of ideas for social reform, or for the radical resolution of Ireland's relationship with Britain, knew no borders. The Irish literary presence in London, be it Shaw or Wilde mixed the projects of achieving literary success and a wider audience with the necessary irony of unresolved relationships, of

has called "a framework for 'a utopia of the Right', based on the separateness of persons”. Michael D. Higgins,

"Responding to the Crisis", Renewing the Republic, Dublin, Liberties, 2011, p. 55.

11. Higgins, "Of Public Intellectuals".

12. Ibid.

13. Ibid. 
Irishness. This would have a lasting effect, not only on the artistic form, but on the consciousness of audiences ${ }^{14}$.

Although he perhaps too easily sidesteps the contradiction between Shaw's pacifism and Connolly's violent uprising, Higgins diplomatically places part of the intellectual paternity of the Rising outside of its realm, outside of Ireland, commenting: "In so many ways the tragedy of modern Ireland's recent difficulties is that it did what the founders of the LSE hoped. It was the first English-speaking country to decolonise ${ }^{15}$."

In essence, Higgins relates or maps a narrative of liberation that is partially common to London and Dublin. However, in contrast to such an originary paradigm, he subsequently diagnoses that the history of the independent state was marked in its early phase by an imbalance which neglected the economic side of things, while, in the period of its recent excesses, "leaders and people had all but lost connection with the cultural and political elements of national revival which might, if retained, have provided an ethical brake, made a critique that would have constituted the regulation that was needed ${ }^{16 "}$. In other words, the initial Irish anti-colonial liberation was in large measure the product of the emancipatory, democratic interrelation of the realms of the metropolis and the periphery, where one was in dialogue with and ultimately involved in the other. As a model for consciousness, such an active, travelling and "literary" paradigm would have prevented the imbalance of either extreme, whether in the form of the reification of passive, supposedly authentic peasants of the early decades after independence, or the atomised self-centred and passive consumers of recent times.

This interconnected paradigm which he offers in relation to culture and economics, to the relationship of the academy and the world, and to Ireland's colonial past, is also very relevant to the context of his own intervention. He draws attention to this at the very beginning of his LSE speech. After referencing the extent to which he feels at home in London, he turns to the visit nine months earlier of the Queen to Ireland, so inviting the interpretation that his visit to the UK should be understood in relation to the earlier visit. The Queen had been made to feel at home in the place of the other, and she, in turn, had diplomatically corresponded with the proposal of, as she put it, a "shared narrative" and an interconnected genealogy which did not demand that her interlocutor surrender his/her own claim to independent identity. Higgins states that:

Her Majesty's visit, her perfectly judged words, her gesture of respect for those who died in an Irish cause, her use of the Irish language, her 
evident pleasure at being our honoured guest, symbolised the remarkable transformation in relations between our countries over recent years and it was deeply welcomed all over the island of Ireland ${ }^{17}$.

Having noted the success of the visit, he pays tribute to his predecessor, Mary McAleese. One could conclude that in Higgins's approach, and in the reciprocal 2014 state visit of the Irish President to the UK, we can find a continuity in the sensitivity to figurative, poetic or literary language that allowed his predecessor to engage in a rapprochement with the Queen on her state visit, when attempts were made to deploy narratives of interconnection and to achieve the performance of communality in, for example, the parallel remembrances at the memorial sites of those who had fought both for and against the Crown. To conclude that Higgins is a mere follower would, however, be to do a disservice to him, particularly considering that he was an intellectual influence, even a pioneer, in the utilization in Ireland of the sort of language which we broadly call postcolonialism.

In his address to the LSE, he interprets British-Irish history in terms of colonisation while simultaneously drawing a narrative of anti-colonialism which is ideologically sourced in the metropolitan centre, or more correctly, in the traffic between Ireland and Britain embodied by the creative writer and public intellectual, Shaw. In doing so, he draws attention to the performative potential of language to symbolise peace over conflict, and to map out a common space of equal and democratic participation by both sides. We could similarly interpret President McAleese's Dublin Castle speech welcoming the Queen in which, while tracing interconnected narratives of belonging, she also clearly spoke of the historical relationship as one of coloniser and colonised. And the fact that McAleese used such vocabulary, along with the sort of diplomatic gestures Higgins lauded in the Queen, has to be linked to the critical discourse over previous decades of academics who have used the language of postcolonialism. Among these we have to place Higgins himself.

Consider, for example, his 1990 Hot Press article "Building the Black and Green Alliance ${ }^{18 ”}$, published 21 years before Barack Obama lauded the connection between Frederick Douglass and Daniel O'Connell, and long before that central figure of Irish postcolonial criticism David Lloyd would come to write of the Black and Green Atlantic ${ }^{19}$. This was also the year of Field Day's publication of the three key essays by Edward Said, Terry Eagleton and Fredric Jameson which

17. Ibid.

18. Michael D. Higgins, "Building the Black and Green Alliance", Causes for Concern, Dublin, Liberties, 2006, p. 119-123.

19. David Lloyd and Peter D. O'Neill, eds., The Black and Green Atlantic: Cross-currents of the African and Irish Diasporas, Hampshire, Palgrave Macmillan, 2009. 
many consider to really inaugurate Irish postcolonial studies ${ }^{20}$. In Higgins's article he examines the history of the language of stereotype and of its relationship to the cementing of the hegemony of colonial power, which inscribed the metropolis as civilised and the periphery as savage, and so legitimised violence against the latter. He also does so in a conscious riposte to Conor Cruise O'Brien whose revisionism focussed on what he saw as the need of the Irish to examine their dangerous myths in the interest of embracing a modernity which would let them take their place in the civilised world. O'Brien, however, Higgins feels, only addresses one side and fails to deal with the abuse of language in empowered discourses which historically inscribed the Irish as primitive, and which involved a project "of the cultural extinction of everything native and the superimposition on it of what was assumed to be a God-ordained superiority that the coloniser or the Empire possessed $^{21}$ ". Revisionism, he believes, only goes in one direction, in a simple narrative of progress determined by the metropolitan centre.

Higgins shows how such a narrative of modernisation is seriously skewed in its representation of history. If critical positions of this nature were then finding expression in terms increasingly described as postcolonial critique, Higgins had been a significant early contributor to the debate. For example, in "The Tyranny of Images, Literature, Ethnography and Political Commentary on the West of Ireland $^{22}$ " - originally published in 1983 in the Crane Bag, that key precursor to Field Day founded by Richard Kearney and Mark Patrick Hederman - he examines how academic discourse, particularly that of ethnography and the high culture of revivalism, served to give intellectual legitimacy to a myth of a homogenous peasantry and to the idea of a community rooted in one place. Ultimately, the idea of the atavistic, self-willed intransigence of the rural West is, he proposes, a fake, and reveals how "the corpse of the colonised can be exhumed in the form approved by the gatekeeper for the dominant culture, reflecting faithfully the literary and aesthetic norms of the coloniser ${ }^{23}$ ". The reality was one of circular migration. As he points out, well before the Famine hugely significant seasonal migration back and forth to Britain was in fact the norm.

Consequently, when the colonised embrace a model of modernity legitimised by metropolitan interests, a concept expressed on the terms of the metropolis, then, in Higgins's words, "the colonised take to themselves the version the coloni-

20. Seamus Deane (ed.), Nationalism, Colonialism and Literature, A Field Day Company Book, By Fredric Jameson, Terry Eagleton and Edward Said, Minneapolis: University of Minnesota Press, 1990.

21. Higgins, "Building the Black and Green Alliance", p. 121.

22. Michael D. Higgins, "The Tyranny of Images, Literature, Ethnography and Political Commentary on the West of Ireland", Causes for Concern, Dublin, Liberties, 2006, p. 137-156.

23. Ibid., p. 142. 
sers have of them ${ }^{24 "}$. Instead they must, he says, achieve the right to tell their own story. He writes:

We need to look at how we have been colonised and how we can incorporate our experience of colonisation to turn the tables on the coloniser, even if that means marriage to the coloniser's daughter, with the particular historical resonance that has in Irish history. We do need to ask what has been done in the name of objectivity, neutrality, impartiality and balance. We need to ask whose consensus these values have served ${ }^{25}$.

Ultimately, the ability to shape and tell an appropriate story that gives an adequate form to the postcolonial reality involves, as he writes in a 1993 lecture, "Culture, Democracy and Participation ${ }^{26 ", ~ a ~ s o r t ~ o f ~ m i g r a t i o n ~ f r o m ~ a c a d e m i c ~ l a n-~}$ guage to poetry. This implies a mode of cultural activism within which historical echoes of language are redefined through the process of reinterpretation and rearticulation. In Higgins's sensitivity to the complex historical resonances of language can be identified a resistance to the exclusive deployment of language as a tool of utilitarian use reminiscent of a similar resistance in the work of the former Crane Bag editor, Richard Kearney. Writing in relation to the work of Brian Friel, Kearney values the critical potential in the use of poetry to contest dominant orthodoxies whose discourse of pragmatism masks exploitative power relations:

Friel opposes this ontological model of language to the positivist use of words as agents of pragmatic progress. This alternative positivist model is perhaps most closely associated with the philosophy of British Empiricism, which served in recent centuries as the ideological mainstay of British colonialism [...]. Positivism maintains that words are mechanically given [...] objects in a world of similar objects. They are eminently unmysterious entities to be used as instruments for the representation, mapping or classification of reality. And the reductionist goal of positivism is to produce an exact decoding of the world by establishing a oneto-one correlation between words and the facts of empirical experience. Language is thus reduced to a utilitarian weapon for the colonisation of Being. It murders to dissect ${ }^{27}$.

We can surmise from the poetic work of Higgins, and in the insistence on the interaction, interconnection or dialogue between poetic language and that of politics or "factual", positivistic, academic discourse, such as that of revisionist history

26. Michael D. Higgins, "Culture, Democracy and Participation", Causes for Concern, Dublin, Liberties, 2006, p. $157-163$.

27. Richard Kearney, Navigations: Collected Irish Essays 1976-2006, Dublin, Lilliput, 2006, p. 269. 
or modernisation theory, an attempt to redress the legacy of "the colonisation of Being" as Kearney put it, and so engineer or remap a new space of more democratic relations. In his "The Tyranny of Images" essay Higgins writes:

$[F]$ rom the end of the nineteenth sixties through the seventies, there has been a native empiricism reflecting the training, mostly abroad, of the first wave of post-clerical sociologists, who have acquired their sociological training in the positivistic tradition of American sociology. They have approached the west and its problems from the perspective of modernisation theory. The [...] Taoiseach, Garret FitzGerald, an economist, is a loose affiliate of this school. His proposals for so-called western development - a massive injection of capital and the institutional framework through which it would flow - remind me of a television advertisement for all-round worm drench ${ }^{28}$.

Higgins, perhaps too casually dismissive of the considerable intellectual scope of FitzGerald's work, here focusses on the American strain of what is the broad Anglo-Saxon tradition of positivism critiqued by Kearney. Although trained in this tradition, in the US and the UK, Higgins soon became disillusioned particularly by what he saw as its distrust of language and the complicity of modernisation theory in the hegemony of aggressive capitalist values, with the consequence that, as he has written: "Freedom has been defined and reduced to market freedom ${ }^{29}$.

Part of Higgins's rebellion against the dominant strain has involved what he sees as the need to ensure "the democratic right of everyone to have their story told $^{30 "}$. In short, as he states in "My Education", "That is what makes me write poetry ${ }^{31}$ ". Reviewing key influences on his own intellectual development, he highlights not his training in sociology at Indiana and Manchester universities but the formative influence of his primary school teacher, William Clune. This decision to attach importance to the figure of Clune is clearly intentioned, and an example of the sort of cultural and critical activism which seeks to go against the grain of the hegemonic model which resists unconventional interpretations of the complex historical resonances of language. For Higgins, an appropriate paradigm of education is not one which is conceived as a series of stages of maturity, each involving the pragmatic achievement of progressively more substantial goals, but rather it is a model more akin to that practiced by Clune. Clune, he writes:

\footnotetext{
28. Michael D. Higgins, “The Tyranny of Images”, Causes for Concern, Dublin, Liberties, 2006, p. 144-145.

29. Michael D. Higgins, "Education for Freedom", Causes for Concern, Dublin, Liberties, 2006, p. 33.

30. Michael D. Higgins, "My Education”, Causes for Concern, Dublin, Liberties, 2006, p. 23.

31. Ibid.
} 
[...] defeated time because he was going back as well as forward. [...] He was a man who loved the wonder of children, and he had some extraordinary ideas, which I am sure couldn't be proved. He had an idea, for example, that if you tried hard enough and used your concentration, you could go back through not only your own memory but other people's memories to remember an Irish word. He was a Jungian ${ }^{32}$.

Higgins goes on to clarify that his recollections of childhood should not be understood as a romanticising of rural Ireland, or as, in his words, "pastoral nonsense ${ }^{33}$ ". In tune with his evocation of poetic resonances from his early years he is at pains to highlight the social side of the life he lived and he does so by recalling how the house of his aunt and uncle with whom he lived was "caving in" and had broken windows ${ }^{34}$. In this combination of the poetic and the social we can recognise the radical idiom of postcolonial interpretation which in the Irish context achieves its most potent expression in a critical archaeology which seeks to give voice to subaltern subjects, the fragments of whose stories have been occluded by the dominant narrative of modernisation.

Social scientist Bryan Fanning, in his 2008 study The Quest for Modern Ireland: The Battle of Ideas 1912-1986, attempts to chart what he terms "the contours of Ireland's primary post-colonial intellectual schism" by means of the polarities which he ascribes to the key magazines The Bell and The Crane Bag ${ }^{35}$. Fanning proposes that a revisionist, modernising tradition, which in his view was pioneered by The Bell and characterised by a preoccupation with "real social problems", gained continuity through the academic work of social scientists and empiricist historians but was eventually challenged by philosophers, poets and academics in the field of literature, first through The Crane Bag and subsequently by what he terms "the big bang [...] driven by post-colonial theory ${ }^{36 "}$ " In somewhat dismissive terms, Fanning subsequently deals with Richard Kearney's exploration of the Irish mind as a Jungian collective consciousness and of the relationship of art to politics. Kearney proposed that imagination should be valued as highly as reason and that the strict division between the two which was espoused by liberal humanist revisionists such as Conor Cruise O'Brien was essentially fallacious. But Kearney then goes on to link this involvement of the imagination in the realm of the material with the potential that every man has "to discover his own freedom from the existing world [...]. It is an open invita-

32. Ibid., p. 23-24.

33. Ibid., p. 24.

34. Ibid.

35. Bryan Fanning, The Quest for Modern Ireland: The Battle of Ideas 1912-1986, Dublin, Irish Academic Press, 2008, p. 5.

36. Ibid., p. 5-6. 
tion. No one is excluded ${ }^{37}$. For much that Fanning appears to wish to depict Kearney's work as the metaphysical musings of a philosopher disconnected from practical realities, from "real social problems", it is apparent that, like the postcolonial criticism which followed, it very clearly aims to bring influence to bear in the political world and to do so in a manner which has the potential to radically challenge the Anglo-centric value system which gains expression in the language of modernisation.

As is clear in the coincidence between the model of art and politics espoused by Kearney and that evident in the connection made between poetry and liberation by Higgins, as well as in his interpretation of the role of the public intellectual, both hold broadly overlapping philosophical views and these also coincide with those of many of the most notable exponents, in an Irish context, of what has come to be known as postcolonial theory. While we can consider Kearney as a seminal influence, it is also appropriate to recognise that, from an early stage, Higgins also championed broadly similar values.

Eóin Flannery has summarised in the most significant recent study on postcolonial studies and Ireland that "Postcolonial theory emerged in the 1980s as a discursive alternative to modernisation theory, becoming a means through which the putative progressive certainties of modernisation could be dislodged or, at least, contested ${ }^{38}$. And in many of the signal, self-consciously postcolonial interventions in Irish critical discourse we can trace a continuity with the concerns addressed by Kearney, but also by Higgins. For example, Luke Gibbons's influential essay "Coming out of Hibernation: The Myth of Modernization in Irish Culture", originally published in a 1988 volume edited by Kearney, examines, in terms reminiscent of Higgins's 1984 "The Tyranny of Images" article from The Crane Bag, how the representation of rural Ireland, and particularly the West, has been largely fabricated in the metropolitan centre. David Lloyd's interrogations of modernity also attempt to interpret historical time in a fashion which contests the apparent logic of capitalist conceptualisations of progress with a view to elaborating a politics which retrieves from the ruins of Irish history and the barely traceable echoes of damaged voices from the past the potential for a radical reimagining of social relations in more liberating directions ${ }^{39}$. Lloyd's work has also

37. Ibid., p. 12-13.

38. Eóin Flannery, Ireland and Postcolonial Studies: Theory, Discourse, Utopia, Hampshire, Palgrave, Macmillan, 2009, p. 13. Flannery's contention is borne out by the key collection of essays in the field, Clare Carroll and Patricia King eds., Ireland and Postcolonial Theory, Cork, Cork University Press, 2003. Contributions from Joe Cleary, David Lloyd, Clare Carroll, Luke Gibbons, Kevin Whelan and Seamus Deane all interrogate aspects of modernity and its impact on Ireland. Other key interventions in the debate on the tensions between modernisation and postcolonialism include, Conor McCarthy, Modernisation: Crisis and Culture in Ireland 1969-1992, Dublin, Four Courts, 2000; and Colin Graham, Deconstructing Ireland: Identity, Theory, Culture, Edinburgh, Edinburgh University Press, 2001.

39. See David Lloyd, Irish Times: Temporalities of Modernity, Dublin, Field Day, 2008 and David Lloyd, Irish Cul- 
addressed how the modern state, particularly through the apparatus of education, functions to repress or marginalise cultural and social forms resistant to modernisation, rendering them as belonging "to the domain of non-sense $\mathrm{A}^{40}$ ". In Higgins's "poetic" retrieval of figures such as his non-conventional schoolmaster William Clune, or others who echo through his poetry, and the "ruined" lives of family members from his childhood, particularly his republican father who was abandoned by the new state, he puts into practice a challenge not only to the hegemonic values of modernity but also to the Irish state of which, paradoxically, he has become the symbolic representative ${ }^{41}$.

As a poet/politician Higgins can be interpreted as a living embodiment of Kearney's paradigm of the Irish mind which, he hypothesises, "does not reveal itself as a single, fixed homogenous identity ${ }^{42}$ ". Kearney clarifies: "In contradistinction to the orthodox dualist logic of either/or, the Irish mind may be seen to favour a more dialectical logic of both/and: an intellectual ability to hold the traditional oppositions of classical reason together in creative confluence ${ }^{43}$ ". Crucially, he argues that this does not imply, as colonial prejudice would have it, that the Irish "abandoned order for disorder" but that it signified "another kind of meaning ${ }^{44 "}$. While the stable, rational subject is the mainstay of modernity, Kearney's non-conventional, contradictory paradigm can be seen as characteristic of the Irish postcolonial mind.

Ultimately, we are dealing with the proposal of a model of consciousness which is, as Edward Said, suggests, primarily spatial. In "History, Literature and Geography 45 ", originally spoken to an audience of academics at the University of Cairo, Said laments the extent to which literature and history have historically been cordoned off into separate discreet entities:

Neither history nor literature are inert bodies of experience; nor are they disciplines that exist out there to be mastered by professionals and experts. The two terms are mediated by the critical consciousness, the mind of the individual reader and critic, whose work [...] sees history and literature somehow informing each other. So the missing middle term between history and literature is therefore the agency of criticism, or - interpretation ${ }^{46}$.

ture and Colonial Modernity 1800-2000: The Transformation of Oral Space, Cambridge, Cambridge University Press, 2011.

40. David Lloyd, Ireland after History, Cork, Cork University Press, p. 35.

41. The title poem, "The Betrayal", of Higgins's first poetry collection deals with the death in poverty of his father.

42. Richard Kearney, "Introduction. An Irish Intellectual Tradition?: Philosophical and Cultural Contexts", The Irish Mind: Exploring Intellectual Traditions, ed. Richard Kearney, Dublin, Wolfhound Press, 1985, p. 9.

43. Ibid.

44. Ibid.

45. Edward W. Said, "History, Literature and Geography”, Reflections on Exile, London, Granta, 2000, p. 453-473. 46. Ibid., p. 457. 
The implications of Said's model go beyond the consideration of the appropriate realms of academic enquiry to issues such as, in Kearney's words, "the colonisation of Being". Real agency, largely the right to independent being or the ability to interpret and critique the world, and to imagine and articulate one's own story to this same world, refuses, for example, the strict classification of peoples into primitive and civilised or backward and modern. Similarly, real agency rejects the alternative of a false resolution or reconciliation such as that proposed by the incorporation of peripheral identity into the dominant metropolitan mainstream, in other words, the elimination or conversion of its dissonant stories, or its strange and deviant myths, to the pragmatic common-sense norm.

Said here draws a contrast between his spatial paradigm and what he terms a broadly Hegelian model of temporality ${ }^{47}$. He notes that most modern Western literary histories are consistent with this "Hegelian" model, and the history or "story" of the dominant bourgeoisie with a world view that is "mercantile, individualistic, and enterprising 48 ". And he proposes that the "overall advance of the dominant mainstream ${ }^{49}$ " involves the resolution of contradiction in the shape of the solidification of a simple, clear, and non-contradictory core identity.

Against this tendency, Said defends what he terms "an essentially geographical, territorial apprehension of human history and society ${ }^{50}$ ", with Antonio Gramsci here serving as the great prototype. In essence Said proposes, in a manner notably consistent with the ideas defended by Higgins, that history "derives from a discontinuous geography ${ }^{51}$ ". In other words, history and particularly History as a discipline, as much as an objective expression of empirically verifiable truth, or the teleological expression of modernisation, is situated, the product of complex social struggles particularly over territory. And in response to this comprehension of the relationship between culture and politics or power, Said advocates a critical positioning, the development of "a certain type of critical consciousness" which he believes "is geographical and spatial in its fundamental coordinates ${ }^{52}$ ".

Such a spatial critical consciousness is what we find in Higgins's refusal of modernisation theory in Ireland, is apparent in his mapping of historical realities of circular migrations, back and forth, and in his proposal of the value of a constant intellectual traffic between spaces, realms, institutions and nations. As Said indicates of Gramsci, this involves facing in more than one direction. Literature, or "poetic" discourse is consonant with such a spatial consciousness, encou- 
raging as it does metaphorical language which displaces meaning and invites different, alternative interpretations, in short the telling of a variety of stories.

This paradigm also demands that abstract ideas travel from the academy to the "real" world, and requires culture, literature and poetry to become the currency of an inclusive public space. Higgins proposes in "Culture, Democracy and Participation" that it is in the development of community arts that "we are liberating our citizenry from the determinism of a narrow economic consumerism ${ }^{53}$ ". Social pas-

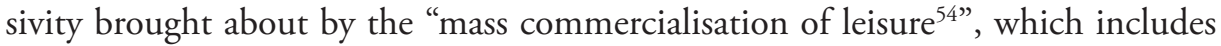
reality-show culture, means the atomisation of life and a radical individualism that mitigates against a vital public space and democracy. Ultimately, the route to overcoming this malaise is that which is necessary to overcome the legacy of a colonial history. Acknowledging the key role theorists on the relationship between the coloniser and the colonised, such as Frantz Fanon and Albert Memmi, have had in exposing the complicity of hierarchical notions of cultural value in the suppression of non-metropolitan culture and peoples and in their exclusion from power, Higgins ventures a process of healing with creative, cultural expression in public places at its heart ${ }^{55}$ : "It requires having access to the creativity of the self in interaction with others ${ }^{56}$ " and, as he concludes: "All these issues are about how we look at each other and either avert our gaze or celebrate our interdependency ${ }^{57}$."

Crucially, for Higgins the logic of such a spatial, poetic model of Being involves the remapping of social, economic, cultural and political relations with the former colonial centre but also in solidarity and dialogue with subaltern populations across the world. In Causes for Concern a section on the public space, and on the importance of culture in facilitating the critical sensibilities that promote a model of active citizens rather than passive consumers, is followed by one relating Ireland to the rest of the world. In effect, the achievement of the right, and the real ability, to tell one's one story with liberty is predicated on the need not just to proclaim that particular story but also to connect it to others. The genuinely active citizen must have as his or her public space not just the local place but that of the whole of humanity.

53. Michael D. Higgins, "Culture, Democracy and Participation”, Causes for Concern, Dublin, Liberties, 157-163, p. 161.

54. Ibid., p. 162.

55. Since his election Higgins has reiterated his belief in the public employment of culture and creative social participation in view of, for example, its potential in processes of healing such as that in Northern Ireland. This he does in dialogue with the scholarly work on the concepts of memory and healing carried out within the broadly hermeneutical tradition by Richard Kearney and Paul Ricœur. See Michael D. Higgins, "Of Migrants and Memory”, [www.president.ie/speeches/], 2012.

56. Michael D. Higgins, "Culture, Democracy and Participation”, p. 161.

57. Ibid., p. 163. 
Higgins chooses to conclude Causes for Concern with a 2006 speech "The Task of the Left: Towards a Politics Beyond the Self ${ }^{58}$ ", given when President of the Labour Party and addressed to both the party and Dublin City University. Then, as the title indicates, he proposed that, ultimately, the future task of the Left was the development of the sort of critical consciousness we have been outlining, and the development of policies designed to shift people from their contemporary role as passive spectators so that they become reconnected and included in a vibrant democratic society. This involves going beyond the self to interaction with others and a conscious and public rebuttal of "a current politics that asserts an aggressive individualism over the social ${ }^{19}$ ". We find a succinct expression of Higgins's values, those which later marked his election campaign and are at the heart of his presidency, here proposed in the hope of affording a renewed symbolic resonance to the nation. Such values are not just the stuff of any contemporary popular or populist vogue, but are the result of years of in-depth, nuanced scholarship and his attempts to engage a broad spectrum of people with the ideas such scholarship consistently proposed to him. Higgins, then referring to the upcoming general election in 2006, forcefully proposed that the debate in politics should not just be about "changing the managers ${ }^{60}$ ", when the values that underlay the system were so problematic as to challenge politics itself. The debate, he says, should also be about space and time. In our current bind, in what he calls "the depeopled economy", society is under pressure for time, with individuals feeling increasingly obliged to give constant evidence of their utility in sustaining "the needs of the economy ${ }^{61 "}$. By checking this temporal paradigm through invoking a critical language which valorises the potential of space to be interpreted as encouraging a public or non-private engagement with others, and so be "beyond the self", a regeneration of society may be possible. In short, the very idea of citizenship should be based on the promotion of interdependency because, as he suggests, "the capacity to go beyond oneself, towards others, to take their needs and lives into account, is the prerequisite of all human solidarity and the viability of society. It is the only real definition of citizenship ${ }^{62 "}$.

58. Michael D. Higgins, "The Task of the Left: Towards a Politics Beyond the Self", Causes for Concern, Dublin, Liberties, p. 321-324.

59. Ibid., p. 321.

60. Ibid., p. 322.

61. Ibid., p. 323-324.

62. Ibid., p. 322. In 2013 Higgins gave two key addresses "Towards a European Union of the Citizens" to the European Parliament and "Defining Europe in the Year of the European Citizen" at the University of Paris, The Sorbonne. In both active citizenship was emphasised with the role of intellectuals and politicians in the involvement of the people proposed as paramount to functioning democracies and a universal community in which the rights of all are respected. In his Sorbonne speech Higgins stressed the importance of "intellectual migrants", those prepared to go beyond the protected walls of academia, and the moral courage of intellectuals who contest the distortion of narratives of the past and whose critical scholarship has been essential to 
Ultimately, this is the language of diplomacy. It is the language of peace and solidarity which demands a self-consciousness shaken from the dull, passive consumption of what Edward Said has called "pre-packaged information that dominates our thought ${ }^{63 "}$ and lulls us into submission. It is the language that moves us off the sofa and away from what Higgins has termed "commoditised entertainment on television ${ }^{64}$ ", towards a rewarding engagement with others and the sharing of more complex, enriching narratives.

In the promotion of this broadly literary idiom, his words, gestures and symbols provide paradigms of interaction which potentially allow for more enabling realities. Said, speaking to an audience in the University of Cape Town, South Africa, and invoking the example of John Henry Newman as an argument against specialisation, suggested that the model for academic freedom should be the migrant or the traveller. We should, Said feels, be free:

to discover and travel among other selves, other identities, other varieties of the human adventure. But, most essentially, in this joint discovery of self and Other, it is the role of the academy to transform what might be conflict, or contest, or assertion into reconciliation, mutuality, recognition and creative interaction ${ }^{65}$.

These words are appropriate to the intellectual and ethical values of Michael D. Higgins. So too is Said's concluding image in which, in the interest of his defence of the idea of the scholar as a quester after both knowledge and freedom, he draws a contrast between the sort of academic model of the professional who seeks to be "king and potentate", he who reigns over his domain and seeks to defend above all else his authority, and the traveller. The traveller, who can move at ease between The Magic Mountain and debates on land reform, is, Said proposes, more playful, but no less serious, and is dependent not on power but motion, willing to enter different worlds, to "use different idioms, and understand a variety of disguises, masks, and rhetorics ${ }^{60}$ ". But, above all, the traveller exchanges fixed routine for what is new, and abandons pre-determined patterns and dogmas, crossing over in diplomacy to the space of the other. This paradigm is the cultural idiom of academic freedom but it is also the truly liberationist spirit

emancipatory movements. He here highlights the seminal role played by Denis Diderot in confronting the exploitative projects of empire. Michael D. Higgins, "Towards a European Union of the Citizens", [www.president.ie/speeches/], 2012. Michael D. Higgins, "Defining Europe in the Year of the European Citizen", Études Irlandaises, Vol. 38, n 1, 2013.

63. Edward W. Said, Humanism and Democratic Criticism, New York, Columbia University Press, 2004, p. 93.

64. Michael D. Higgins, "The Task of the Left", p. 324.

65. Edward W. Said, "Identity, Authority, and Freedom: The Potentate and the Traveler", Reflections on Exile, London, Granta, 2000, p. 387-404, p. 403.

66. Ibid., p. 404. 
of a republic. Logical, then, and appropriate given Higgins's scholarly lineage, that such a travelling intellectual equipped with his creative, political and cultural passport should have been, in his symbolic rapprochement with the British monarch in the spring of 2014, the plenipotentiary to inaugurate a genuinely post-colonial reality. 